Meyer, L. M., Nuller, F. R., Rowen, M. J., Bock, G., and Rutzky, J. (1950). Acta haemat., Basel, 4, 157.

Nichol, C. A., and Welch, A. D. (1950). Proc. Soc. exp. Biol., N.Y., 74, 403 .

Pierce, M., and Ait, H. (1948). J. Lab. clin. Med., 33, 1642.

Sacks, M. S. (1949). Ann. intern. Med., 30, 867.

Bradford, G. T., and Schoenbach, E. B. (1950). Ibid., 32, 80.

Sauberlich, H. E. (1949). J. biol. Chem., 181, 467.

— and Baumann, C. A. (1948). Ibid., 176, 165.

Smith, J. M., Cosulich, D. B., Hultquist, M. E., and Seeger, D. R (1948). Trans. N.Y. Acad. Sci., 10, 82.

Stickney, J. M., Mills, S. D., Hagedorn, A. B., and Cooper, T. (1949). Proc. Mayo Clin., 24, 525.

Thiersch, J. B., and Stock, C. C. (1949). Cancer, $2,863$.

Weber, E. J., Karpinski, F. E., and Heinle, R. W. (1950). J. pediat., 36, 69.

Weir, D. R., Heinle, R. W., and Welch, A. D. (1948). Proc Soc. exp. Biol., N.Y., 69, 211.

- Welch, A. D., and Heinle, R. W. (1949). Ibid., 71, 107.

Woolley, D. W. (1947). Physiol. Rev., 27, 308.

\section{TUBERCULOUS MENINGITIS}

\section{RESULTS OF TREATMENT WITH STREPTOMYCIN AND INTRATHECAL SULPHETRONE}

BY

W. L. CALNAN, M.D., D.C.H.

Registrar, Whittington Hospital (Archway Group)

J. RUBIE, M.D., M.R.C.P., D.C.H.

First Assistant, Paediatric Department, St. George's Hospital ; sometime Registrar, Whittington Hospital

AND

A. F. MOHUN, M.D.

Pathologist, Archway Group Laboratory

At a special unit for the treatment of tuberculous meningitis at Highgate Hospital 48 patients were treated between May, 1948, and November, 1949. These patients were included in a controlled trial of "sulphetrone" given intrathecally. All except three were under 15 years of age. The results of the trial form the subject of this report. Forty-seven cases were proved bacteriologically.

A sulphone derivative (tetrasodium 4:4'-bis( $\gamma$-phenylpropylamino)-diphenylsulphone- $\alpha ; \gamma ; \alpha^{\prime}-\gamma^{\prime}-$ tetrasulphonate), which has been given the registered name "sulphetrone,"* has been shown to possess high antibacterial activity against the tubercle bacillus with comparatively low toxicity (Brownlee, 1948). Smith, McClosky, and Emmart (1946) have shown that the effect of streptomycin is enhanced by the addition of a sulphone, and a synergistic action of the two compounds has been demonstrated in guinea-pigs (Brownlee and Kennedy, 1948).

\section{Treatment}

The intrathecal route of administration was considered advisable because of: (1) the small amounts of the drug found in the brain and cisternal fluid after intravenous or oral administration in animals (Brownlee, 1948) ; (2) the difficulty of daily intravenous administration in infants and young children; (3) the irregular absorption from the intestinal tract in children, particularly when

*We wish to thank Messrs. Burroughs Wellcome and Co. for supplies of sulphetrone in a form suitable for intrathecal injection. constipated; (4) the pain caused by intramuscular injection and the relatively large volume required.

Dosage.-The dosage was $200 \mathrm{mg}$., given with the daily dose of streptomycin intrathecally in the same syringe. Higher doses than this were tried, but were abandoned owing to the greatly increased incidence of convulsions.

C.S.F. and Serum Levels.-With this dosage, cerebrospinal fluid (C.S.F.) and serum concentrations of sulphetrone were very low-0-3 mg. per $100 \mathrm{ml}$. of serum, and 0-4 mg. per $100 \mathrm{ml}$. of C.S.F. at 24 hours after injection. Higher levels occurred in a few patients and were accompanied by convulsions.

Toxic Effects.-Toxic effects encountered were convulsions ( 5 cases), excessive head retraction and opisthotonos ( 7 cases), mental symptoms (3 cases), and cyanosis (1 case). In five patients the reactions were severe enough to necessitate interruption of treatment. Abnormal blood pigments were not identified and anaemia was not found, although the plasma showed a deep maroon discoloration.

Streptomycin.-The periods during which streptomycin was given to all patients are shown in the Chart. The daily dose was $0.02 \mathrm{~g}$. per $1 \mathrm{lb}$. $(0.45 \mathrm{~kg}$.) body weight in 24 hours intramuscularly and $0.1 \mathrm{~g}$. in $10 \mathrm{ml}$. of normal saline intrathecally.

Miliary Disease of Lung.-Nine cases showed miliary disease of the lungs-four were in the streptomycin plus sulphetrone series (all survived) and five in the streptomycin only series (two survived).

\section{Results}

The 48 patients were all consecutive admissions who had not received any previous treatment. At first, alternate patients (irrespective of age and stage of disease) were given sulphetrone, and the remainder were used as controls. Later, when it was decided to subdivide the cases into groups so as to avoid either series being unduly "weighted" with infants or advanced cases, in whom an unfavourable outcome might be expected, the patients were first classified on admission according to age and stage of disease. Each patient was then allocated to the appropriate division of the six shown in Table I. Within each of these six divisions,

TABLE I.-Showing Age and Stage of Disease in Sulphetrone and Control Groups

\begin{tabular}{|c|c|c|c|c|c|c|c|}
\hline \multirow{2}{*}{$\frac{\text { Stage of Disease: }}{\text { Age Group: }}$} & \multicolumn{2}{|c|}{ Early } & \multicolumn{2}{|c|}{ Middle } & \multicolumn{2}{|c|}{ Advanced } & \multirow{2}{*}{ Total } \\
\hline & $\begin{array}{l}\text { Under } \\
3 \mathrm{yr} \text {. }\end{array}$ & $\begin{array}{l}\text { Over } \\
3 \text { yr. }\end{array}$ & $\begin{array}{l}\text { Under } \\
\mathbf{3} \text { yr. }\end{array}$ & $\begin{array}{l}\text { Over } \\
3 \text { yr. }\end{array}$ & $\begin{array}{l}\text { Under } \\
3 \mathrm{yr} \text {. }\end{array}$ & $\begin{array}{l}\text { Over } \\
3 \text { yr. }\end{array}$ & \\
\hline $\begin{array}{l}\text { Streptomycin (con- } \\
\text { trol group) } \\
\text { Streptomycin and sui- } \\
\text { phetrone (sulphe- } \\
\text { trone group) }\end{array}$ & 5 & 3 & 3 & 10 & 2 & 2 & 24 \\
\hline
\end{tabular}

alternate cases received streptomycin and sulphetrone, and the remainder received streptomycin alone. By this method an approximately equal number of patients were treated with and without sulphetrone in the two age groups and at each stage of disease on admission. Current admissions were used as control cases, so that any minor advantages in treatment recently developed would apply equally to both series.

The results of treatment are shown in Table II. All patients have been observed for a minimum period of 


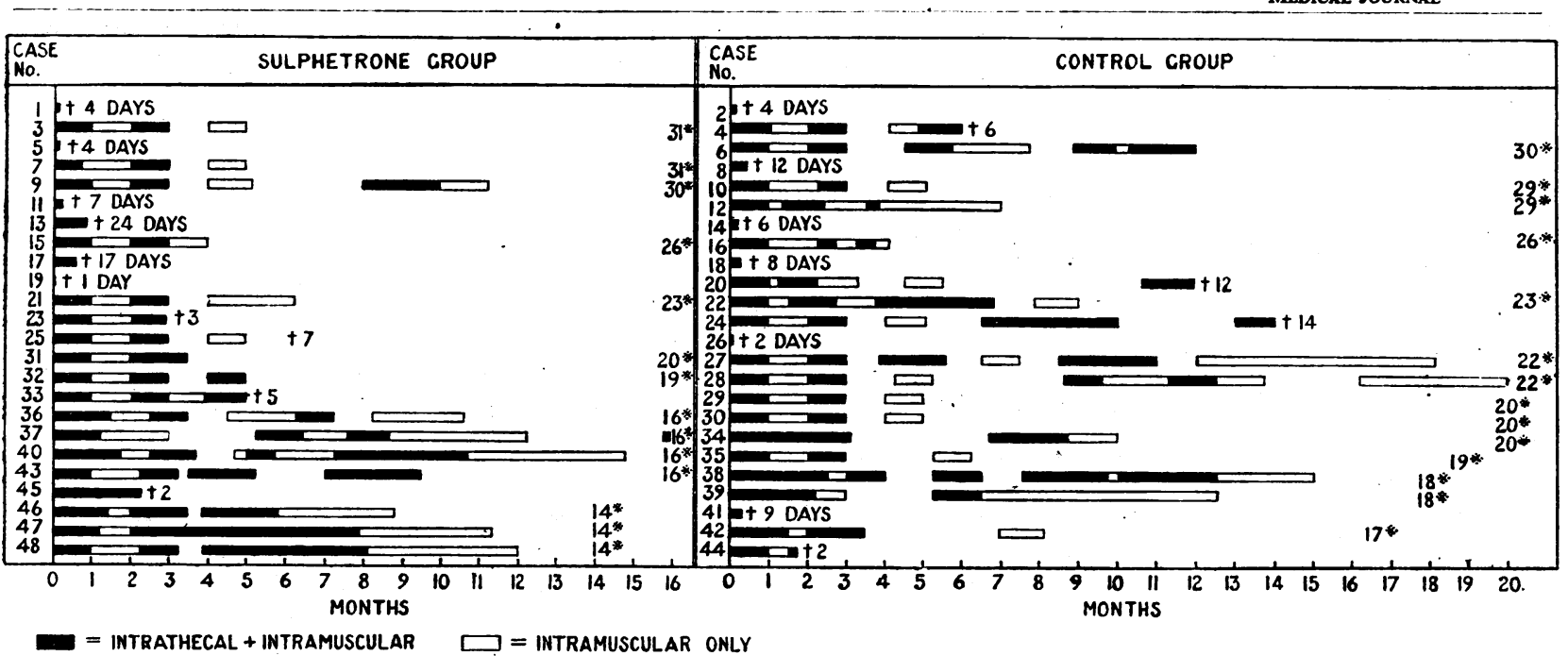

Chart showing periods, up to December, 1950, during which streptomycin was given to all cases. Cases are numbered serially according to date of admission. ${ }^{*}$ Figures with an asterisk denote survival periods in months from start of treatment. $\dagger=$ Death.

twelve months from the start of treatment. The survival rate in the two groups was the same. In addition to the crude survival rate no appreciable clinical difference was found between the two groups.

TABLE II.-Results of Treatment (Survivors After 12 Months Minimum Observation)

\begin{tabular}{|c|c|c|c|c|c|c|c|}
\hline Stage of Disease* : & \multicolumn{2}{|c|}{ Early } & \multicolumn{2}{|c|}{ Middle } & \multicolumn{2}{|c|}{ Advanced } & \multirow[b]{2}{*}{ Total } \\
\hline Age Group: & $\begin{array}{l}\text { Under } \\
3 \text { yr. }\end{array}$ & $\begin{array}{l}\text { Over } \\
3 \text { yr. }\end{array}$ & $\begin{array}{l}\text { Under } \\
3 \text { yr. }\end{array}$ & $\begin{array}{l}\text { Over } \\
3 \text { yr. }\end{array}$ & $\begin{array}{l}\text { Under } \\
3 \text { yr. }\end{array}$ & $\begin{array}{l}\text { Over } \\
3 \text { yr. }\end{array}$ & \\
\hline $\begin{array}{l}\text { Survivors: } \\
\text { Streptomycin }\end{array}$ & 4 & 2 & $\mathbf{0}$ & 7 & .0 & 1 & 14 \\
\hline $\begin{array}{c}\text { Streptomycin and } \\
\text { sulphetrone }\end{array}$ & 3 & 2 & 1 & 8 & $\mathbf{0}$ & 0 & $\begin{array}{l}(58 \%) \\
14 \\
(58 \%)\end{array}$ \\
\hline Total .. & 7 & 4 & 1 & 15 & 0 & 1 & 28 \\
\hline
\end{tabular}

*The criteria for classification of patients according to the stage of disease on admission are those recommended by the Medical Research Council(1948).

\section{Discussion}

In view of the close similarity of the composition of the "treatment" and "control" series in terms of age and stage of disease, the finding of exactly similar survival rates in the two groups is certainly significant and confirms our clinical impression that sulphetrone, when injected intrathecally, is of no value in the streptomycin treatment of tuberculous meningitis.

When this trial was started, no other reports of the use of sulphetrone intrathecally were available. Two reports have since been published. Fouquet et al. (1949) treated an unstated number of patients with the addition of a sulphone (diaminodiphenylsulphone) intrathecally. They reported $59 \%$ cured among the sulphonetreated group, and $53 \%$ among the controls, treated with streptomycin alone. Rist and Cottet (1949) treated a series of 20 patients with the same sulphone intrathecally. They used a dose of $2-3 \mathrm{mg}$. per $\mathrm{kg}$. body weight daily. During rests from intrathecal treatment they gave a total daily dose of $3-4 \mathrm{mg}$. per $\mathrm{kg}$. body weight by mouth. A control series of 39 patients was treated with streptomycin alone. Patients who died during the first month of treatment were excluded. The control group showed a survival rate of $52 \%$, as against $72 \%$ in the sulphone-treated group. The authors attributed the improved results in the latter group to the reduction in deaths due to streptomycin-resistant strains of tubercle bacilli, during the fourth to sixth month of treatment.

In the 48 cases covered by the present report, significant streptomycin resistance* has been encountered as follows: In one patient, in bacilli isolated on the thirteenth day of treatment (thousandfold resistance); in one patient at the eleventh month of treatment (thousandfold resistance); in a third patient at the seventh month of treatment (160-fold resistance). None of these patients was treated with intrathecal sulphetrone, but the incidence of resistance is clearly too low to permit any conclusions to be drawn concerning the effect of sulphetrone in this respect.

\section{Summary}

A controlled trial of intrathecal sulphetrone in addition to streptomycin for tuberculous meningitis is reported. The dose of sulphetrone given was $200 \mathrm{mg}$. daily.

Toxic reactions necessitated interruption of treatment in 5 out of 24 cases treated.

The crude survival rate after a minimum of 12 months' observation was the same $(58 \%)$ in both the treated and the control grouips. The results combined with our clinical observations do not indicate that sulphetrone injected intrathecally is of value when added to the streptomycin treatment of tuberculous meningitis.

We wish to thank the following for advice and help: Dr. S. Yudkin, paediatrician, Whittington Hospital; Dr. J. M. Alston, pathologist, Archway Group Laboratory; Miss M. F. Crowley, biochemist, Archway Group Laboratory; the numerous laboratory technicians who helped with the pathological work; Dr. ${ }^{C}$. D. Coyle, medical superintendent, Whittington Hospital, and Sister S. E. Robinson and the nursing staff who had the care of the patients treated in the unit.

\section{REFERENCES}

Brownlee, G. (1948), Lancet, 2, 131.

$\longrightarrow$ and Kennedy, C. R. (1948), Brit. J. Pharmacol., 3, 37.

Fouquet, J., Heimann, V., Meyer, B., and Hennequet, J. (1949). Bull. Soc. méd. Hôp. Paris, 65, 553 .

Medical Research Council (1948). Lancet, 1, 582.

Rist, N., and Cottet, J. (1949). Pr. méd., 57, 743.

Smith, M. I., McClosky', W. T., and Emmart, E. W. (1946). Proc. Soc. exp. Biol., N.Y., 62, 157.

*Streptomycin resistance is defined in relation to the standard strain H37Rv, and we have taken 32-fold resistance as being probably the minimum significant level. The clinical significance of resistance less than several hundredfold is still not established. 